\title{
Conflict Avoidance as Linguistically Reflected in English and Javanese
}

\author{
Adnan Zaid \\ Universitas Teknologi Yogyakarta \\ adnan56zaid@yahoo.com
}

\begin{abstract}
By and large, normally people do their best not to lose their face and not to hurt their interlocutor's feeling in communication. They exert their efforts to make their interlocutors honored or even flattered. This phenomenon happens both in the spoken and written forms of language. Words or sentences which may result in conflicts between speakers and listeners, and writers and readers are avoided. Instead, words or sentences which are soothing, comforting, easing, relieving, or encouraging are chosen. To some degree, a successful speaker or writer attempts to make his/her audience secured and happy, not offended or hurt. The failure to employ the right words or expression in communication may result in miscommunication. Most importantly, people avoid being rude in saying things to their interlocutors.

This paper tries to explore how conflicts are avoided linguistically in English and Javanese. It is aimed at finding out the words, phrases and sentences which are employed to minimize any conflict which may arise when communication takes place. English is a relatively old language which has polite expressions to lessen any tense which may happen when two or more people interact linguistically. Javanese is popular for being a polite language which is rich in soft or polite expressions which are employed to avoid conflicts in communication. In Javanese, even there is a language level called krama madya or krama inggil in which there is a slight chance to have any conflict when people use this kind of diaglosia. This paper will also expose some similarities and differences in strategy for conflict avoidance in English and Javanese, and will seek some kind of universality in language with regard to minimizing conflicts.
\end{abstract}

Keywords: avoidance, conflict, communication, English, Javanese

\section{INTRODUCTION}

To communicate effectively, people exert their efforts to make their interlocutors feel secured, free from being threatened or hurt. Misunderstanding and conflict are avoided for the sake of smooth communication. Choice of words is employed for this purpose. Certain linguistic strategies may be made to avoid offending interlocutors. This phenomenon may occur in asking someone to do something, apologizing, disagreeing, saying no, declining, and the like.

English and Javanese are no exception in this case. Despite the distance between Indonesia and UK, English and Indonesian may have some similarities in the way how to avoid conflicts in communication. Of course there will be some differences due to different cultures because language and culture are inter-related. The use of certain expressions isfound in English, while Javanese uses a certain level of language called krama to eliminate any possible conflict. In Javanese, there is a wise word "ajining diri gumantung ing lati" (one's dignity depends on his language). Language plays a paramount role in communication. Linguistically, one should not hurt or offend his/her listener to lead a harmonious life. Among Javanese, there is a principle of respecting and living in harmony (MagnisSuseno, 1985:38). This principle is linguistically expressed in Javanese.

\section{Conflict Avoidance}

When one communicates verbally, he/she has to try not to hurt his/her listener or reader. In other words, he/she tries to avoid any conflict while the communication is going on. This is realized in certain polite linguistic devices for certain occasions such as requests, offers, compliments, apologies, thanks, greetings, leave takings, addressing, and the responses to these. Even, this phenomenon occurs when one wants to say no or to refuse an offer. People always try to be polite to avoid any conflict or misunderstanding. Politeness is a battery of social interaction skills whose goal is to ensure everyone feels affirmed in social interaction (Foley, 2001). 
Brown and Levinson (1987) argue that politeness strategies are developed in order to save the hearer's "face", meaning that people try to avoid embarrassing the other persons, or making them feel uncomfortable. Linguistically, people avoid conflict which may generate from verbal communication. Words, phrases, or sentences are uttered or written in such a way that the listener or the reader may feel comfortable while the process of communication is in progress. This phenomenon can be found out in English and Javanese.

\subsection{Conflict Avoidance in English}

English speaking people value politeness over directness. They are more likely to forgive inaccuracies than rudeness. English speakers assume implicitly that speakers are mostly concerned about ensuring that their own individual needs are met, and that others are not imposed on (Brown and Levinson, 1987). Being polite is a must to ensure smooth communication. Choice of words plays an important role in order to avoid any conflict. This notion can be seen on some occasions in communication. In being polite, for example, one may use the word please, modal, euphemism, tag question, or certain address terms.

Close the door, please. (Please)

Could you please speak more loudly? (Modal)

She is expecting a baby. (Euphemism)

You don't mind, do you? (Question tag)

Be careful, honey. (Address term)

In order not to hurt the interlocutor's feeling, some expressions are used to say no, to decline, or to disagree. In saying no, one does not directly say no. Instead, he/she will say some expressions such as:

I'd love to, but ...

I really appreciate the offer, but ...

That sounds great, but ...

I'm afraid I can't ...

I'm not really fond of ...

Thank you very much, but I have to ...

That's a good idea, but ...

I think it is too ... to ...

To disagree with someone, a civil society demands someone to express disagreement in a polite way to minimize any inconvenience. To say "I disagree" is too direct. Instead, one may use the following expressions for this purpose:

I'm afraid I disagree.

I beg to differ.

I am not sure about that.

Not necessarily.

I don't see it that way.

I'm sorry but I don't agree.

Yes, but ...

Well, in my opinion ...

Actually, I think ...

In declining an invitation, one does not say no directly. Instead he/she may use certain expressions such as: 
Thank you very much for the invitation, but I have to ...

That's great, but I ...

I'm so sorry, but I ...

Thank you for inviting me to .... Unfortunately, I ...

\subsection{Conflict Avoidance in Javanese}

Among Javanese, there is a principle of living in harmony. In line with this principle, one has to behave in such a way that he/she will not create a conflict (Magnis-Suseno, 1985). This practice is seen, among others, in the way Javanese people use language. Javanese people have to be careful in using language so that they will not create any conflict, maintaining the principle of living in harmony.

In Javanese, there are at least three levels of language, namely ngoko (low level), krama madya (middle level), and krama inggil (high level). Ngoko is used among friends, krama madya is used to speak to older people or strangers, and krama inggil is used to communicate to respectful people. When people use the krama madya or even krama inggil, they can hardly say rude words to hurt other's feeling. In other words, people can avoid any conflict by speaking in krama madya or krama inggil.

Indirectness in Javanese is one of the strategies to be polite in order not to create any conflict. For example, when a husband comes home from his work and there is no drink served on his table, he may ask his spouse by saying "Sumure asat pa Bu?" (Literally, is the well dry, Honey?". It does not mean that he asks about the well. Rather, he asks his spouse indirectly to serve him some drink.

In saying no, a Javanese person will not frontally say no. Rather, he/she may give some reasons, not just saying no. For example:

Mr. Bejo: Panjenengan dados ketua panitia nggih Pak? (You become the chief of the committee, won't you?)

Mr. Satrio: Mbok sanese mawon Pak. Kula napa pantes dados ketua? (Please choose another person, Sir. Am I the right person?)

Another way to decline something in Javanese is by saying "Nyuwun ngapunten" (Please forgive me), or "Nuwun sewu" (I am sorry).

Pak Sudiman: Panjenengan saged tindak rapat ta? (Could you go to the meeting?)

Pak Legiyo: Nyuwun ngapunten. Kula wonten acara sanes. (I'm sorry. I have another agenda.)

In this conversation Pak Legiyo does not directly say no. Instead, he apologizes and gives a reason for not being able to come.

$\mathrm{Bu}$ Ratmi: Panjenengan saged rawuh pepanggihan mbenjang sonten, Bu? (Could you come to the meeting tomorrow afternoon, Mam?)

Bu Shinto: Nuwun sewu, Jeng. Kula wonten keperluan sanes. (I am sorry. Mam. I have gotsomething else to do.)

Here, Bu Shinta does not say no directly, either. She apologizes and gives a reason for not being able to attend the meeting.

To disagree, a Javanese will not directly express his/her disagreement. He/she apologizes first, and then he/she says something related to his/her opinion. For example:

Jeng Sri: Wah piknike larang banget ya?(The picnic is so expensive, isn't it?)

Jeng Tari: Nek nurut aku kok ra larang banget. Biasa wae. (In my opinion, it is not so expensive. Reasonable.)

Jeng Tari does not respond negatively. To avoid a conflict, she just expresses her own idea about the topic. 


\section{SimILARITIES AND DIFFERENCES}

Although Javanese and English are spoken by their native speakers living far away from each other, the two languages share something in common in relation to conflict avoidance. There are some words, phrases or sentences in both languages, which are utilized to minimize any conflict due to verbal communication.

In English, some special expressions are employed to say no, to decline, or to disagree. In Javanese, indirectness plays an important role to minimize any conflict. Besides, the phrases "Nyuwun ngapunten"(Forgive me) and "Nuwun sewu" (I am sorry) are mostly used to say no, decline, or disagree. In Javanese, the use of krama madya and krama inggil is quite effective to avoid any conflict that may arise in communication. People can hardly argue or say rude words when they employ krama madya or krama inggil. There is no such a level of language in English.

\section{Concluding Remark}

To get along with other people harmoniously and to avoid conflict in communication, linguistically civilized people employ some strategies. The strategies can lieon the form of some special expressions to show some kind of politeness, or on the form of a certain level of language.

The above phenomenon is found in English and Javanese. There are some similar strategies to avoid conflicts in both languages. In the two languages, some special expressionsare employed for the purpose. In Javanese, there is a certain level of language called krama madya and krama inggil which can be used to show politeness and at the same time to avoid any possible conflict. This kind of language level is not found in English. In Javanese, the words nuwun sewu(I am sorry) and nyuwun pangapunten(Forgive me) are used to say no, to decline or to disagree. This is not a common practice in English.

\section{REFERENCES}

Brown, P. and Levinson, C. (1987). Politeness: Some Universals in Language Usage.

Cambridge: Cambridge University Press.

Foley, W. A. (2001). Anthropological Linguistics: An Introduction. Oxford: Blackwell Publishers. Magnis-Suseno, F. 1985. Etika Jawa. Jakarta: Gramedia.

Pranowo, (2009). Berbahasa Secara Santun. Yogyakarta: Pustaka Pelajar. 